\title{
Use of multi-primer / multi-gene PCR method for the detection of Mycobacterium tuberculosis among female genital tuberculosis patients in India
}

\author{
Venkanna Bhanothu ${ }^{1 *}$, Jane Theophilus ${ }^{1}$, Roya Rozati ${ }^{2}$, AVikram Aiman ${ }^{3}$ \\ From 2nd International Science Symposium on HIV and Infectious Diseases (HIV SCIENCE 2014) \\ Chennai, India. 30 January - 1 February 2014
}

\section{Background}

Female genital tuberculosis (FGTB) is a silent disease that evidences itself only when it is investigated. Demonstration of the etiologic agent by $\mathrm{H} \& \mathrm{E}$ staining or Z-N staining for acid fast bacilli, smear microscopy, and culture of sputum and other body fluid specimens were often less specific.

\section{Methods}

A prospective case-control study was undertaken. A total of 302 endo-ovarian tissue biopsies collected from 202 infertile women highly suspected of having genital tuberculosis on laparoscopic examination and from 100 control women of reproductive age. All specimens tested by conventional/phenotypic methods were later compared with multi-gene/ multi-primer PCR method using four sets of primers for detection of Mycobacterium tuberculosis (MTB) in a single tube-single step reaction.

\section{Results}

The conventional methods showed $99 \%$ to $100 \%$ specificity with a low sensitivity, ranging from $21.78 \%$ to 42.08\% while $\mathrm{H} \& \mathrm{E}$ staining showed a sensitivity of $51.48 \%$. Multi-gene PCR method was found to have a much higher sensitivity of $70.29 \%$ with MTB64 gene, $86.63 \%$ with $19 \mathrm{kDa}$ antigen gene at species and TRC4 element at regional MTB complex level and 88.12\% with MPT59 $\alpha$-antigen $/ 32 \mathrm{kDa}$ protein gene at genus level. The specificity of multi gene/multi primer PCR was $100 \%$.

* Correspondence: banothu.venkanna@gmail.com

${ }^{1}$ Department of Zoology, UCS, Osmania University, Hyderabad-7, AP, India Full list of author information is available at the end of the article

\section{Conclusion}

Multi-gene PCR was found to be a powerful technique for diagnosis and differentiation of mycobacterial infection among endo-ovarian tissue biopsies taken from infertile patients with FGTB. We suggest site specific sampling and amplification of the $19 \mathrm{kDa}$ antigen gene in combination with TRC4 element as a successful multi-gene/ multi-primer PCR method for the diagnosis of FGTB.

\section{Authors' details}

'Department of Zoology, UCS, Osmania University, Hyderabad-7, AP, India. ${ }^{2}$ MHRT Hospital \& Research Centre, Hyderabad, AP, India. ${ }^{3}$ Gandhi Medical College, Hyderabad, AP, India.

Published: 27 May 2014

\section{doi:10.1186/1471-2334-14-S3-E12}

Cite this article as: Bhanothu et al.: Use of multi-primer / multi-gene PCR method for the detection of Mycobacterium tuberculosis among female genital tuberculosis patients in India. BMC Infectious Diseases 2014

14(Suppl 3):E12.

Submit your next manuscript to BioMed Central and take full advantage of:

- Convenient online submission

- Thorough peer review

- No space constraints or color figure charges

- Immediate publication on acceptance

- Inclusion in PubMed, CAS, Scopus and Google Scholar

- Research which is freely available for redistribution

Submit your manuscript at www.biomedcentral.com/submit
() Biomed Central 